Received: 2020-10-13

\title{
Potential of karamunting (Rhodomyrtus tomentosa) fraction against kidney damage in diabetic rats
}

\author{
MGS IRSAN SALEH $^{1 \oplus}$, RACHMAT HIDAYAT $^{2 *}$, GERI FEBRIYANTO ${ }^{3 \oplus}$, NITA PARISA $^{1 \odot}$
}

\author{
${ }^{1}$ Department of Pharmacology \\ Faculty of Medicine \\ Universitas Sriwijaya \\ Palembang, Indonesia \\ ${ }^{2}$ Department of Biology \\ Faculty of Medicine \\ Universitas Sriwijaya \\ Palembang, Indonesia \\ ${ }^{3}$ Postgraduate Programme \\ Faculty of Medicine \\ Universitas Sriwijaya \\ Palembang, Indonesia
}

*corresponding author: phone: +62 8822505 3819, e-mail: dr.rachmat.hidayat@gmail.com

\section{Summary}

Introduction: Karamunting (Rhodomyrtus tomentosa) is Indonesian native plant that contains high antioxidant compounds with the potential to suppress oxidative stress activity in cells. This study is the first research to specifically explore the role of the karamunting fraction in protecting kidney damage due to the formation of AGEs in the renal glomerulus in diabetes mellitus.

Objective: This study aims to assess the impact of karamunting on blood glucose profile, HbA1c, insulin profile and kidney condition (AGEs expression, TNF- $\alpha$ and kidney histology) in diabetic rats.

Methods: The karamunting extraction process was carried out by maceration with ethanol. Induction of diabetes mellitus was carried out using streptozotocin. Thirty male rats (Rattus norvegicus), Wistar strain weighing between 200-250 grams were the subject in this study. HbAlc, insulin, TNF- $\alpha$, AGEs levels were evaluated in the kidney tissue. Histological assessment of the kidney was carried out.

Results: Karamunting can improve blood glucose levels in diabetic rats. This improvement in blood glucose levels causes an improvement in the level of HbAlc. Administration of karamunting fraction can prevent 
AGEs deposition in renal tissue, which in turn will inhibits the inflammation and prevents further damage of kidneys.

Conclusion: Karamunting fraction can improve blood glucose regulation so that it can prevent further damage and complications of kidney organs in diabetic rats.

\section{Key words: glycated haemoglobin A, insulin, protective agents, oxidative stress, Rhodomyrtus tomentosa}

Słowa kluczowe: hemoglobina glikowana A, insulina, środki ochronne, stres oksydacyjny, Rhodomyrtus tomentosa

\section{INTRODUCTION}

Diabetes mellitus is a clinical condition characterised by systemic impairment of glucose regulation which leads to accumulation of glucose products in blood and tissues[1]. Glucose that accumulates in blood and tissues will react with proteins, nucleic acids or lipids to form various Amadori products which will lead to the formation of advanced glycation end products (AGEs) [1,2]. AGEs are protein modification products and lipids that are responsible for the progression and complications of diabetes mellitus. The kidneys are vital organs that play a role in the filtration of blood, electrolytes and plasma. As a filtration organ, kidneys are the organs most at risk of becoming a buildup of AGEs products $[2,3]$. Accumulation of AGEs products on the renal filtration tissues, the glomerulus, causes activation of the inflammatory cascade. Activation of the inflammatory cascade is responsible for the activation of death receptors from cells which will lead to cell death [3]. A consequence of cell death in the glomerulus and tubule is the decrease of blood filtration function. This condition causes chronic kidney failure. Kidney failure is one of the most common complications experienced by people with diabetes mellitus $[3,4]$, causing the dependence on hemodialysis. Limited hemodialysis facilities cause severe morbidity and mortality, in addition to increasing healthcare cost for patient and state. Therefore, it is essential and urgent to explore new therapeutic modes to prevent severe complications of diabetes mellitus in renal organs due to accumulation of AGEs and chronic inflammation.

Indonesia is a country with the second-largest vegetation wealth in the world. This is an opportunity to develop potential new therapeutic modalities. Karamunting (Rhodomyrtus tomentosa) is one of Indonesia's native plants from the Bangka Belitung archipelago. This plant is a type of shrub with high antioxidant content. Antioxidants are compounds with potential to suppress oxidative stress activity in cells.
In contrast, the accumulation of AGEs in cells and tissues plays a role in the initiation of oxidative stress in cells and tissues [5]. Oxidative stress inhibition causes the inhibition of the inflammatory cascade and inhibition of cell and tissue death and damage.

This study is the first research that seeks to explore the role of the karamunting fraction in protecting against kidney damage due to the formation of AGEs in the renal glomerulus in diabetes mellitus. This study will assess the role of karamunting on blood glucose profile, glycated haemoglobin (HbA1c), insulin profile and kidney condition with a focus on the expression of AGEs, TNF- $\alpha$ and kidney histology.

\section{MATERIAL AND METHODS}

\section{Animal model}

A total of thirty male rats (Rattus norvegicus), Wistar strain were obtained from the Eureka Research Laboratory (Palembang, Indonesia) weighing between 200-250 grams. Animals were kept in cages under controlled conditions of 12 hours of the light-dark cycle, at a temperature of $22 \pm 1^{\circ} \mathrm{C}$ and humidity $40-60 \%$ and given food ad libitum. The research treatments and procedures have received approval from the medical research ethics committee of the Faculty of Medicine, Universitas Sriwijaya (No. 254/ kptfkunsri-rsmh/2020).

\section{Karamunting fractionation preparation}

Karamunting simplicia was obtained from the Tawangmangu Herbal Research Center, Karanganyar, Indonesia. The karamunting extraction process was carried out by maceration in which 500 grams of simplicia were macerated with $96 \%$ ethanol for 72 hours. Furthermore, a proportion between the 
dregs and macerate was carried out. Maceration continued with the fractionation process with $\mathrm{n}$ hexane, ethyl acetate and water solvents, to obtain the n-hexane fraction (FH), ethyl acetate fraction $(\mathrm{FE})$ and water fraction (FA) from karamunting. Karamunting water fraction is a fraction that has been tested and explored more intensively.

\section{Induction of diabetes mellitus}

Induction of diabetes mellitus was carried out using streptozotocin (STZ) compounds (Sigma Aldrich, Singapore). A total of $55 \mathrm{mg} / \mathrm{kg}$ BW solution of STZ in citrate buffer $(0.1 \mathrm{M}, \mathrm{pH} 4.5)$ was injected intraperitoneally in overnight fasted rats [6]. Nondiabetic controls were injected with citrate buffer (0.1 M, pH 4.5). After seven days of STZ induction, fasting blood glucose levels were measured with a spectrophotometer (Biorad, Singapore). Rats with a blood glucose concentration higher than $200 \mathrm{~g} / \mathrm{dl}$ were categorised as diabetic rats.

\section{Chronic treatment with karamunting fraction}

The rats were divided into six groups, namely: group 1: non-diabetic white rats, group 2: streptozocininduced diabetes mellitus rats without treatment, group 3-6 rats with induced diabetes mellitus given glibenclamide $5 \mathrm{mg} / \mathrm{kg}$ BW (Dexamedica, Palembang, Indonesia) [7]. Karamunting fraction was administered at a dose of $10 \mathrm{mg} / \mathrm{kg} \mathrm{BW;} 20 \mathrm{mg} / \mathrm{kg}$ BW and $40 \mathrm{mg} / \mathrm{kg} \mathrm{BW}$. Glibenclamide and fractions were given for 30 days.

\section{Blood sample collection}

A blood sample was taken from the orbital vein on the first day after overnight fasting. After 30 days of administration with standard drugs or karamunting fraction, the rats that fasted overnight were sacrificed, and blood samples were taken for biochemical examination. $\mathrm{HbAlc}$ was measured in blood samples that had been collected in the EDTA tube with the rat $\mathrm{HbAlc}$ assay kit. Insulin was measured from blood samples using an ELISA Insulin rating (Cloud Clone, Hangzhou, China). Blood glucose measurement was carried out with a spectrophotometer (Biorad, Singapore). Before being stored at $-20^{\circ} \mathrm{C}$, the blood samples in the EDTA tube were centrifuged (Biorad, Singapore) at a speed of $5000 \mathrm{rpm}$ at $25^{\circ} \mathrm{C}$, for
10 minutes. The supernatant was collected and stored to be used as a sample for biochemical testing.

\section{Evacuation of experimental animal's kidney}

Before organ evacuation, the Wistar rat was anaesthetized. Furthermore, the operation was performed on the flank area with an incision of about 5 centimetres to obtain the kidney. Next, the kidneys are evacuated and divided, where some are put into ice-packed containers, and some into boxes filled with $10 \%$ NBF liquid (normal buffer formalin). The kidneys that were put into the ice-packed containers were homogenized and centrifuged at a speed of $5000 \mathrm{rpm}$, for 30 minutes at $4^{\circ} \mathrm{C}$. The supernatant was then taken and stored in a centrifuge tube at $-20^{\circ} \mathrm{C}$, to check the levels of TNF- $\alpha$ and AGEs. Parts of kidneys that had been placed in $10 \% \mathrm{NBF}$ solution were prepared for histopathological examination.

\section{ELISA (Enzyme-Linked Immunosorbent As- say): HbAlc, insulin, TNF- $\alpha$, AGEs}

Rat ELISA HbAlc was used to asses $\mathrm{HbAlc}$, insulin, TNF- $\alpha$, AGEs levels in the kidney tissue. Insulin, TNF- $\alpha$, AGEs (Cloud Clone, Hangzhou, China) were based on the protocol contained in the manufacturer's protocols (sensitivity of ELISA kit 92\%). Briefly, $50 \mu \mathrm{l}$ of standard diluent or serum samples were added to the well and incubated at $37^{\circ} \mathrm{C}$ for 30 minutes. After the plates were washed, $100 \mu \mathrm{l}$ of the biotinylated antibody solution was added and set for 30 minutes at $37^{\circ} \mathrm{C}$. After washing three times, $50 \mu \mathrm{l}$ avidin-peroxidase complex solution was added and incubated for 15 minutes at $37^{\circ} \mathrm{C}$. After washing, $50 \mu \mathrm{l}$ of tetramethylbenzidine colour solution was added and set in the dark for 15 minutes at $37^{\circ} \mathrm{C}$. Finally, $50 \mu \mathrm{l}$ stop solution was added to stop the reaction, and the optical density (OD) was measured using an ELISA reader (Biorad, Singapore) at the wavelength of $450 \mathrm{~nm}$. By analysing the standard curve of the standard of each examination protein, the levels of HbAlc, insulin, TNF- $\alpha$ and AGEs were obtained.

\section{PAS (Periodic acid-Schiff) histological exami- nation staining}

Kidney tissue that was fixed with $10 \%$ NBF was dehydrated using graded alcohol and xylene, then paraffinised and cut to a thickness of $5 \mu \mathrm{m}$, using 
a rotary microtome (Leica, Illinois, USA). The results of the cut were then placed on a glass object, added to the Shiff's reagent, left for 5-7 minutes and then stained with Mayer's Hemalaum solution for 3 minutes. Subsequently, wash, dehydration, clearing in xylene and mount with mounting media were carried out. Histopathological changes in synovial tissue were analysed under a microscope (Olympus, Tokyo, Japan).

\section{Phytochemical test}

\section{Test for phenols}

The test was performed by the method of Sofowora [8]. $2 \mathrm{ml}$ extract was taken in a beaker glass. Then, $2 \mathrm{ml}$ of ferric chloride solution was added. A deep bluish-green solution indicated the presence of phenols.

\section{Test for terpenoids}

Salkowski test was performed by using the method of Edeoga et al. [9]. $5 \mathrm{ml}$ of aqueous extract was mixed with $2 \mathrm{ml}$ of chloroform. Then, $3 \mathrm{ml}$ of concentrated sulfuric acid was poured to form a layer. A reddish-brown colouration of interface indicated the presence of terpenoids.

\section{Test for saponins}

The test was performed using the method of Edeoga et al. [9]. $2 \mathrm{~g}$ of the powdered sample was boiled in $20 \mathrm{ml}$ of distilled water in a water bath and filtered the solution. Then, $10 \mathrm{ml}$ of filtrate was mixed with $5 \mathrm{ml}$ of distilled water and shaken vigorously for a stable, persistent foam. The foam was mixed with three drops of olive oil and shaken vigorously, which led to the formation of the emulsion, which indicated the presence of saponins.

\section{Test for flavonoids}

The test was performed with the method of Harborne [10]. $1 \mathrm{~g}$ of powdered sample was heated with $10 \mathrm{ml}$ ethyl acetate over a steam bath $\left(40-50^{\circ} \mathrm{C}\right)$ for 5 minutes. The filtrate was treated with $1 \mathrm{ml}$ od diluted ammonia. A yellow colouration demonstrated positive test for flavonoids.

\section{Test for alkaloids}

The test was performed by using the method of Harborne [10]. $1 \mathrm{~g}$ powdered sample was extracted with $5 \mathrm{ml}$ of methanol and $5 \mathrm{ml}$ of $2 \mathrm{~N}$ hydrochloric acid. Then the filtrate was tested with Meyer's and Wagner's reagents. The samples were scored positive, based on turbidity.

\section{Statistical analysis}

All data was presented as mean \pm standard deviation, and all statistical analysis was performed with the SPSS 25 (IBM, Jakarta, Indonesia) software. One way ANOVA followed by post hoc analysis, was carried out, to assess the difference in mean expression levels of each protein. $p<0.05$ indicated that there was a significant difference in mean levels.

\section{RESULTS}

Table 1 shows the potential for karamunting fraction on glucose regulation in Wistar rats. Karamunting extract was able to improve blood glucose levels in rats. This improvement in blood glucose levels causes an improvement in the level of glycosylated haemoglobin (HbA1c). Karamunting fraction has shown the increase of insulin secretion from the pancreas, which is believed to improve blood glucose regulation.

Table 2 provides an overview of the potential for karamunting fraction in inhibiting complications of kidney problems in people with diabetes mellitus. The karamunting fraction can improve the directional glucose regulation so that there is an inhibition of AGEs deposition in the renal tissue. It can inhibit inflammation and the inflammatory cascade played by TNF- $\alpha$ expression.

Figure 1 is a histopathological picture, as well as cross-check of the results of biochemical and molecular markers on the cellular image. Figure 1 shows that administration of karamunting fraction can prevent AGEs deposition in renal tissue, which in turn will inhibit inflammation and prevent further damage to the kidneys.

Table 3 shows that each karamunting water fraction is rich in flavonoids with very high antioxidant potential. Flavonoids are the primary and secondary metabolites believed to play a role in inhibiting inflammation and oxidants due to the accumulation of AGEs. 
Table 1.

Effect of karamunting extract on glucose regulation

\begin{tabular}{ccccccc}
\hline \multirow{2}{*}{ Groups } & \multicolumn{2}{c}{ Fasting blood glucose $[\mathrm{mg} / \mathrm{dl}]$} & \multicolumn{2}{c}{ HbAlc $[\mu \mathrm{g} / \mathrm{ml}]$} & \multicolumn{2}{c}{ Insulin $[\mathrm{IU} / \mathrm{ml}]$} \\
\cline { 2 - 7 } & Day 1 & Day 30 & Day 1 & Day 30 & Day 1 & Day 30 \\
\hline 1 & $89.9 \pm 6.87$ & $87.8 \pm 5.37$ & $3.9 \pm 0.17$ & $3.8 \pm 0.27$ & $188.2 \pm 15.32$ & $188.1 \pm 16.65$ \\
\hline 2 & $389.9 \pm 26.71$ & $399.9 \pm 28.27$ & $12.8 \pm 0.82$ & $12.9 \pm 0.65$ & $32.8 \pm 0.11$ & $32.9 \pm 0.13$ \\
\hline 3 & $382.2 \pm 21.13$ & $181.3 \pm 11.27^{\star}$ & $12.5 \pm 0.76$ & $7.8 \pm 0.23^{\star}$ & $32.4 \pm 0.21$ & $123.1 \pm 10.12^{\star}$ \\
\hline 4 & $384.3 \pm 23.21$ & $299.2 \pm 24.57^{\star}$ & $12.3 \pm 0.43$ & $10.1 \pm 0.95^{\star}$ & $32.3 \pm 0.12$ & $87.8 \pm 4.65^{\star}$ \\
\hline 5 & $383.2 \pm 27.97$ & $197.3 \pm 16.47^{*}$ & $12.9 \pm 0.68$ & $7.9 \pm 0.44^{*}$ & $32.1 \pm 0.22$ & $124.3 \pm 10.12^{\star}$ \\
\hline 6 & $386.6 \pm 26.57$ & $169.9 \pm 10.22^{\star}$ & $12.6 \pm 0.77$ & $6.9 \pm 0.33^{\star}$ & $32.3 \pm 0.23$ & $132.9 \pm 11.22$ \\
\hline
\end{tabular}

${ }^{*}$ ANOVA, post hoc Bonferroni, $p<0,05$ vs group 2; group 1: non-diabetic rat; group 2: streptozocin-induced diabetes without treatment; group 3: streptozocin-induced diabetes with glibenclamide treatment $(5 \mathrm{mg} / \mathrm{kg} \mathrm{BW})$; group 4: streptozocin-induced diabetes rats with karamunting fraction $(10 \mathrm{mg} / \mathrm{kg} \mathrm{BW})$; group 5: streptozocin-induced diabetes rats with karamunting fraction $(20 \mathrm{mg} / \mathrm{kg} \mathrm{BW})$; group 6: streptozocin-induced diabetes rats with karamunting fraction $(40 \mathrm{mg} / \mathrm{kg} \mathrm{BW})$;

Table 2.

Effect of karamunting extract on AGEs and TNF- $\alpha$

\begin{tabular}{ccc}
\hline Groups & AGEs $[\mathrm{pg} / \mathrm{ml}]$ & TNF- $\alpha[\mathrm{pg} / \mathrm{ml}]$ \\
\hline 1 & $17.7 \pm 1.37$ & $89.9 \pm 7.76$ \\
\hline 2 & $989.9 \pm 58.74$ & $1221.4 \pm 87.65$ \\
\hline 3 & $198.3 \pm 16.23^{*}$ & $453.6 \pm 32.23^{*}$ \\
\hline 4 & $249.6 \pm 21.27^{*}$ & $567.8 \pm 43.15^{*}$ \\
\hline 5 & $193.3 \pm 15.57^{*}$ & $447.2 \pm 40.41^{*}$ \\
\hline 6 & $169.9 \pm 13.92^{\star}$ & $398.8 \pm 34.93^{\star}$ \\
\hline
\end{tabular}

*ANOVA, post hoc Bonferroni, $p<0,05 v s$ group 2; group 1: non-diabetic rat; group 2: streptozocin-induced diabetes without treatment; group 3: streptozocin-induced diabetes with glibenclamide treatment $(5 \mathrm{mg} / \mathrm{kg} \mathrm{BW})$; group 4: streptozocin-induced diabetes rats with karamunting fraction $(10 \mathrm{mg} / \mathrm{kg} \mathrm{BW})$; group 5: streptozocin-induced diabetes rats with karamunting fraction $(20 \mathrm{mg} / \mathrm{kg} \mathrm{BW})$; group 6: streptozocin-induced diabetes rats with karamunting fraction $(40 \mathrm{mg} / \mathrm{kg}$ BW)
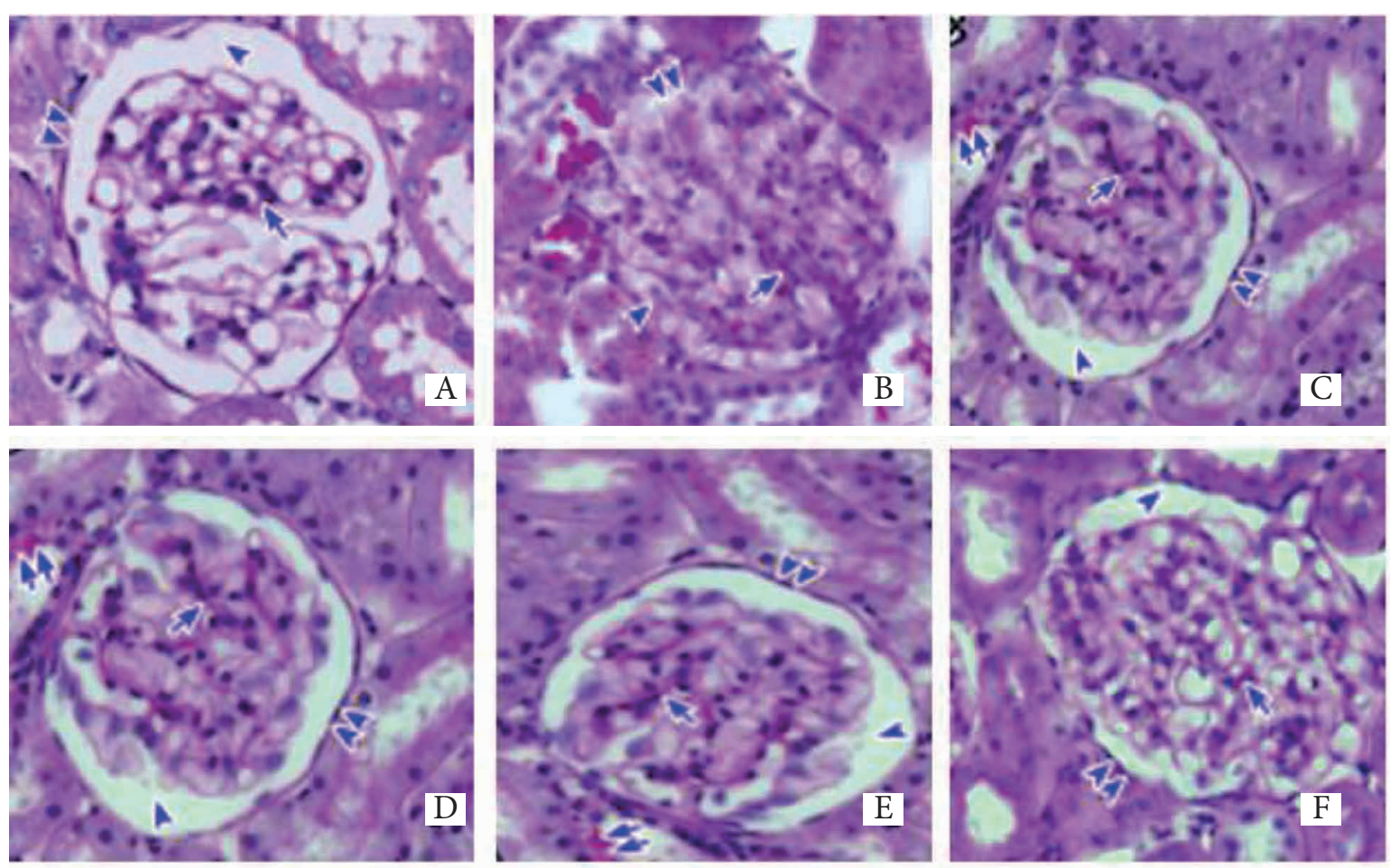

Figure 1.

Histological overview of kidney tissue. PAS Staining. A: group 1, B: group 2, C: group 3, D: group 4, E: group 5, F: group 6. Glycogen deposition (double arrows), Bowman's capsule (double arrowheads), Bowman's space (arrowhead), mesangial area (arrow). $400 \mathrm{x}$ magnification 
Table 3.

Phytochemical test of karamunting fraction

\begin{tabular}{cccccc}
\hline Test material & saponin & alkaloid & triterpenoid & steroid & flavonoid \\
\hline Karamunting fraction & + & + & + & + & ++ \\
\hline
\end{tabular}

Notes: $+++=$ high; $++=$ moderately; $+=$ trace

\section{DISCUSSION}

Karamunting water fraction is a part of further exploration carried out to isolate the presence of polar compounds in the karamunting extract. The karamunting water fraction shows that the flavonoid content is relatively high and is believed to be the primary ad secondary metabolite that plays a role in improving glucose regulation and inhibition of AGEs deposition in kidney tissue. Karamunting is rich in flavonoids with antioxidant potential.

Diabetes mellitus is a clinical disorder with severe oxidative stress due to chronic stress conditions on cells $[1,5]$. Excess glucose intake will lead to overproduction of insulin in pancreatic $\beta$ cells. Pancreatic $\beta$ cells will be stimulated to quick production of large amounts of insulin. This condition causes a lot of misfolded insulin protein which will lead to the accumulation of misfolded insulin protein in the endoplasmic reticulum. This condition causes cell stress which leads to a cascade of oxidative stress [7, 11]. Oxidative stress on pancreatic $\beta$ cells will cause the activation of the inflammatory cascade, which will lead to the activation of death receptors and cause the death of pancreatic $\beta$ cells [12-13]. This condition will lead to insulin deficiency which will worsen glucose regulation [14-16]. The absence of insulin will cause the accumulation of glucose outside the cells in blood vessels and tissues [17-19]. This condition causes a systemic glycosylation process in all organs, especially in kidneys as a blood filtrating organ. This glycosylation process causes the accumulation of AGEs products, which are the reaction products between glucose and proteins, lipids and nucleic acids [18-20].

The accumulation of AGEs in the kidney, especially in the glomerulus, causes the activation of an inflammatory transcription factor that will trigger the activation of the proinflammatory $\mathrm{cy}$ tokine, TNF- $\alpha$ [21-24]. Activation of inflammation in kidneys leads to kidney damage [25-27]. This damage causes decrease the function of kidneys and a role as a filtration organ [28]. Karamunting acts as an antioxidant that will be able to improve oxidative stress conditions in diabetes mellitus [29, 30]. This study proves the ability of karamunting to enhance the regulation of blood glucose, insulin and $\mathrm{HbA1c}$. Good glucose regulation ability will reduce the production of AGEs which will cause the inhibition of AGEs accumulation in tissue [18, 19]. The decrease in AGEs will cause a reduction in the production of proinflammatory cytokines which will lead to repair of damage and deterioration of cell function.

\section{CONCLUSION}

Karamunting fraction can improve blood glucose regulation so that it can prevent further damage and complications of kidney organs in the condition of diabetes mellitus in rat.

Conflict of interest: Authors declare no conflict of interest.

\section{REFERENCES}

1. Singh R, Barden A, Mori T, Beilin L. Advanced glycation end-products: a review. Diabetologia 2001; 44(2):129-146. doi: http://dx.doi. org/10.1007/s001250051591

2. Ahmed N, Babaei-Jadidi R, Howell S, Thornalley P, Beisswenger P. Glycated and oxidized protein degradation products are indicators of fasting and postprandial hyperglycemia in diabetes. Diabetes Care 2005; 28(10):2465-2471. doi: http:// dx.doi.org/10.2337/diacare.28.10.2465

3. Freedman BI, Wuerth JP, Cartwright K, Bain RP, Dippe S, Hershon K, et al. Design and baseline characteristics for the aminoguanidine clinical trial in overt type 2 diabetic nephropathy (ACTION II). Control Clin Trials 1999; 20(5):493-510. doi: http://dx.doi.org/10.1016/s0197-2456(99)00024-0

4. Alam S, Ahsan A, Alam S. Newer insights in drugs inhibiting formation and accumulation of advanced glycation end products. J Biochem Tech 2013; 5:666-672. 
5. Vo TS, Ngo DH. The health beneficial properties of Rhodomyrtus tomentosa as potential functional food. Biom 2019; 9(2):76. doi: http://dx.doi. org/10.3390/biom 9020076

6. Ighodaro OM, Akinloye OA. Anti-diabetic potential of Sapium ellipticum (Hochst) pax leaf extract in streptozocin (STZ)-induced diabetic Wistar rats. BMC Comp Altern Med 2017; 17:525-529. doi: http://dx.doi.org/10.1186/s12906-017-2013-8

7. Cheng D, Liang B, Li Y. Antihyperglycemic effect of Ginkgo biloba extract in streptozocin-induced diabetes in rats. Biomed Res Int 2013; 162724. doi: https://dx.doi.org/10.1155/2013/162724

8. Sofowora A. Screening plants for bioactive agents. In: Medicinal plants and traditional medicinal in Africa. $2^{\text {nd }}$ ed. Ibadan. Spectrum Books, 1993:134156.

9. Edeoga HO, Okwu DE, Mbaebie BO. Phytochemical constituents of some Nigerian medicinal plants. Afr J Biotechnol 2005; 4(7):685688. https://academicjournals.org/article/article1380041849_Edeoga\%20et\%20al.pdf

10. Harborne JB. Phytochemical methods - A guide to modern techniques of plant analysis. $2^{\text {nd }}$ ed. New Delhi. Springer Science \& Business Media, 2005.

11. Zhao Z, Wu L, Xie J, Feng Y, Tian J, He X, Li B, et al. Rhodomyrtus tomentosa (Aiton): a review of phytochemistry, pharmacology and industrial application research progress. Food Chem 2020; 309:125715. doi: http://dx.doi.org/10.1016/j. foodchem.2019.125715

12. Wu P, Ma G, Li N, Deng Q, Yin Y, Huang R. Investigation of in vitro and in vivo antioxidant activities of flavonoid rich extract from the berries of Rhodomyrtus tomentosa (Ait.) Hassk. Food Chem 2015; 173:194-202. doi: http://dx.doi. org/10.1016/j.foodchem.2014.10.023

13. Johnson M. Biochemical variation studies in Aegle marmelos L. Corr: a medicinally important plant. J Chem Pharm Res 2010; 2(6):454-462.

14. Patel PK, Sahu J, Sahu L, Prajapati NK, Dubey BK. Aegle marmelos: A review on its medicinal properties. Int J Pharm Phytopharmacol Res 2012; 1(5):332-341.

15. Kamalakkanan N, Prince PSM. Hypoglycemic effect of water extract of Aegle marmelos fruits in streptozotocin diabetic rats. J Ethnopharma- col 2003; 87(2-3):207-210. doi: http://dx.doi. org/10.1016/s0378-8741(03)00148-x

16. Matthews DR, Hosker JP, Rudenski AS, Naylor BA, Treacher DF, Turner RC. Homeostasis model assessment: insulin resistance and beta-cell function from fasting plasma glucose and insulin concentrations in man. Diabetologia 1985; 28:412419. doi: http://dx.doi.org/10.1007/BF00280883

17. Hafizur RM, Kabir N, Chishti S. Modulation of pancreatic $\beta$-cells in neonatally streptozotocin induced type 2 diabetic rats by the ethanolic extract of Momordica charantia fruit pulp. Nat Prod Res 2011; 25(4): 353-367. doi: http://dx.doi. org/10.1080/14786411003766904

18. Hafizur RM, Kabir N, Chishti S. Asparagus officinalis extract controls blood glucose by improving insulin secretion and $\beta$-cell function in streptozotocin-induced type 2 diabetic rats. Br J Nutr 2012;108 (9):1586-1595. doi: https://dx.doi. org/10.1017/S0007114511007148

19. Siddiqui BS, Hasan M, Mairaj F, Mehmood I, Hafizur RM, Hameed A, et al. Two new compounds from the aerial parts of Bergenia himalaica Boriss and their anti-hyperglycemic effect in streptozotocin-nicotinamide induced diabetic rats. J Ethnopharmacol 2014; 152(3):561-567. doi: http://dx.doi.org/10.1016/j.jep.2014.02.002

20. Hafizur RM, Hameed A, Shukrana M, Raza SA, Chishti S, Kabir N, et al. Cinnamic acid exerts anti-diabetic activity by improving glucose tolerance in vivo and by stimulating insulin secretion in vitro. Phytomedicine 2015; 22(2):297-300. doi: http://dx.doi.org/10.1016/j.phymed.2015.01.003

21. Sachdewa A, Raina D, Srivastava AK, Khemani LD. Effect of Aegle marmelos and Hibiscus rosa sinensis leaf extract on glucose tolerance in glucose induced hyperglycemic rats (Charles foster). J Environ Biol 2001; 22(1):53-57.

22. Kamalakkannan N, Prince PSM. The effect of Aegle marmelos fruit extract in streptozotocin diabetes: a histopathological study. J Herb Pharmacother 2005; 5(3):87-89.

23. Esmaeili MA, Zohari F, Sadeghi H. Antioxidant and protective effects of major flavonoids from Teucrium polium on beta-cell destruction in a model of streptozotocin-induced diabetes. 
Planta Med 2009; 75(13):1418-1420. doi: http:// dx.doi.org/10.1055/s-0029-1185704

24. Noumura E, Kashiwada A, Hosoda A, Nakamura $\mathrm{K}$, Morishita H, Tsuno T, et al. Synthesis of amide compounds of ferulic acid and their stimulatory effects on insulin secretion in vitro. Bioorg Med Chem 2003;11(17): 3807-3813. http://dx.doi. org/10.1016/s0968-0896(03)00280-3

25. Fatima N, Hafizur RM, Hameed A, Ahmed S, Nisar M, Kabir N. Ellagic acid in Emblica officinalis exerts anti-diabetic activity through the action on $\beta$-cells of pancreas. Eur J Nutr 2017; 56(2):591601. doi: http://dx.doi.org/10.1007/s00394-015$1103-y$

26. Papaccio G, Mezzogiorno M. Morphological aspect of glucagon and somatostatin islet cells in diabetic biobreeding and low-dose streptozotocintreated Wistar rats. Pancreas 1989;4(3):289294. doi: http://dx.doi.org/10.1097/00006676198906000-00003
27. Pons P, Aoki A. Differential proliferation of somatostatin and glucagon cells in rat pancreatic islets submitted to different stimuli. Ann Anat 1995; 177(3):221-227. doi: http://dx.doi.org/10.1016/ S0940-9602(11)80189-5

28. Vo TS, Le TT, Kim S, Ngo D. The role of myricetin from Rhodomyrtus tomentosa (Aiton) Hassk. fruit on downregulation of FcERI-mediated mast cell activation. J Food Biochem 2020; 44(3):e13143. doi: http://dx.doi.org/10.1111/jfbc.13143

29. Lai TNH, Andre C, Rogez H, Mignolet E, Nguyen TBT, Larondelle Y. Nutritional composition and antioxidant properties of the sim fruit (Rhodomyrtus tomentosa). Food Chem 2015; 168:410416. doi: http://dx.doi.org/10.1016/j.foodchem.2014.07.081

30. Zhang Y, Li W, Jiang L, Yang L, Chen N, Wu Z, et al. Cytotoxic and anti-inflammatory active phloroglucinol derivatives from Rhodomyrtus tomentosa. Phytochem 2018; 153:111-119. doi: http:// dx.doi.org/10.1016/j.phytochem.2018.05.018 